\title{
A synthesis of the elements of the Orthodox Christian faith, Buddhism and the Enlightenment in Tolstoy's moral-ethical doctrine
}

Leo Nikolayevitch Tolstoy (1828-1910), the count from Yasnaya Polyana, already in his lifetime was a symbol of great hopes and cherished ideals both for the revolutionary intelligentsia and for that group whose background was of a religious character. The writer's output of the last thirty years, i.e., since Confession (Ispoved', 1879-1882) to the set of sentences entitled Way of life (Put'zhizni, 1910), was evidence for his ideological and existential quest.

The research into the content of Tolstoy's moral-ethical doctrine has had a long history. Most scholars support the opinion about the religious nature of the doctrine, resulting from the writer's quest for the idea of complete truth and efforts to put it into life. ${ }^{1}$ There have also been written such interpretations of Tolstoy's works according to which the most important texts have antireligious overtones, ${ }^{2}$ and Tolstoy, in his search, was not able to come back to the source of true faith. ${ }^{3}$

This article aims at following Tolstoy's ideological growth and analysing the content of his most important texts in the light of the changes within the Russian culture of the second half of the $19^{\text {th }}$ century. A selective synthesis of different elements in Tolstoy's doctrine provokes a reflection about the consequences of

${ }^{1}$ Cf. L. Liburska, Późna myśl Totstoja, quasi-uniwersalna synteza [in:] Wizja świata i człowieka w myśli rosyjskiej, ed. L. Suchanek, Kraków 1998, pp. 45-65; M. Zdziechowski, Pesymizm, romantyzm a podstawy chrześcijaństwa, Kraków 1914, Л. Шестов, Добро в учении гр. Толстого и Ф. Ниџще. Философия и проповедь, Париж 1971, В.В. Зеньковский, История русской философии, vol. 1, Париж 1989.

${ }^{2}$ See A. А. Козлов, Религия графа Л. Н. Толстого, Санкт-Петербург 1888; Н. Елеонский, О «Новом Евангелии» графа Толстого, Москва 1887.

${ }^{3} \mathrm{M}$. Abassy, Inteligencja a kultura. O problemach samoidentyfikacji dziewiętnastowiecznej inteligencji rosyjskiej, Kraków 2008, p. 178 
merging ideas from different sources, sometimes fundamentally contradictory to one another.

\section{"A reformed sinner" - Confession}

Tolstoy was born to a noble family and grew up in the atmosphere of material prosperity. Nevertheless, the fear of death cast a shadow over his potentially happy childhood: Tolstoy lost his parents prematurely. As he wrote in his Diary, that death "first triggered the feeling of fear of death." when the writer's brother Mikhail died. Then, for the first time Tolstoy expressed the thought about juxtaposition of life and death, "I was terribly torn from life by that event." Many years later, after a mental crisis and ideological breakthrough that followed it, Tolstoy undertook an intentional effort to find an antidote to the fear which accompanies the thought about death and makes any life meaningless. Confession is evidence of this quest. The title suggests some kind of attempt to carry out an "examination of conscience" and to receive an "absolution"; at the same time the writer is the one who absolves. Tolstoy's contemporary, a professor at St. Petersburg University, Alexander Kozlov, stated that Confession was an instructive sermon, ${ }^{6}$ a parable with a moral about a reformed sinner.

The autobiographical Confession, which is partly a kind of the writer's dialogue with himself, and partly - an effort to express verbally the crucial experience of depression, ${ }^{7}$ and partly - an evaluation, in some places strongly exaggerated, ${ }^{8}$ of the previous period of his life, was started in 1878. 50-year-old Tolstoy was then a father to nine children and husband to the thrifty and, at the same time, well-educated, Sophia. His land estates prospered well, and he had already enjoyed worldwide respect as the author of two great novels: War and peace and Anna Karenina. Gradually, he also gained recognition as a moral authority and philanthropist. There were no obstacles for Tolstoy to live a perfect life. However, these circumstances did not correspond with the writer's mental condition. He was at the peak of his creative power, surrounded by prosperity, when he stated, "My life stopped." The question about the meaning of life endangered by the apparition of death returned with twofold strength. Feeling alienated and in despair, Tolstoy recognized the fact of being mortal as the only

${ }^{4}$ Quoted after: В. В. Зеньковский, vol. 1, p. 392

${ }^{5}$ Ibid., p. 393

${ }^{6}$ А. А. Козлов, Религия графа Л. Н. Толстого, р. 74.

${ }^{7}$ Most scholars describe the condition in which Tolstoy was in that time, as "spirituals crisis." The writer, however, called it a "disease-death,", a "black abbys" and also "madness" (сумасшедствиу). Seе Л. Н. Толстой, Исповедь, ор. cit., pp. 105, 129.

8 Л. Н. Толстой, Исповедь, ор. cit., p. 98; cf. А. А. Козлов, Религия графа Л. Н. Толстого, p. 79.

${ }^{9}$ Ibid., p. 106. 
truth, "Now I am not able any more not to see the days and nights which are passing and leading me towards death. I can see only this because it is the only truth. Everything else is a lie." ${ }^{10}$ It was not a hasty diagnosis. Tolstoy conducted a detailed analysis of the period of his youth and pointed to those aspects which had made him desperate for the meaning of his existence.

The Orthodox Christian religion was the first subject of Tolstoy's criticism. In Confession he admitted, "I was baptized and brought up in the Orthodox Christian faith. I was thought it since my childhood and through the whole period of my adolescence and youth."11 Unfortunately, the teaching was superficial; it did not shape Tolstoy's spirituality and the idea that God is a pure fiction seemed to the writer "interesting and quite possible." 12 He represented the whole generation of the Russian intelligentsia who lost faith because the Orthodox Christian religion did not offer any tools for interpretation of reality that would satisfy an educated Russian nobleman.

"Losing faith in my case happened exactly in the same way as in case of people with our type of education. It happens, it seems to me, in most cases like that: people live, like everybody else, and in their lives they rely on elements which not only have nothing in common with faith, but mostly are contradictory to it." 13 That loss of faith initiated a process of a long-lasting quest for values which could fill an empty place in the writer's soul. After finding out that the Orthodox Church had no correspondence to real life, Tolstoy became fascinated with the idea of moral self-improvement. As he states on the pages of Confession, "Faith in self-improvement was the only true faith for me at that time." 14 The confidence in the power of mind and an act of auto-creation had their roots in the ideas offered by the Enlightenment, and in the 1840s they were reinforced by his interest in Hegelianism. Moreover, they were accompanied by anthropocentrism which guided the Russian intelligentsia (Tolstoy was not an exception) towards a conviction that a human being is the only source and the final purpose of all the changes in the world. However, Tolstoy admitted it himself soon that the imperative of moral self-betterment was transformed into the desire to dominate over the others and to be better than anyone else. ${ }^{15}$ The faith in self-development was interpreted as false and Tolstoy, who wanted to be a good person, invented a new ideal, "to teach people." That idea also had its roots in the Enlightenment thought and, for many years it shaped the mission of the Russian intelligentsia, described as a "service for the social welfare."

\footnotetext{
${ }^{10}$ Ibid., p. 109.

${ }^{11}$ Ibid., p. 94.

12 Ibid.

13 Ibid., p. 95.

${ }^{14}$ Ibid., p. 97.

15 Ibid., p. 97.
} 
Tolstoy called it a "new faith which was expressed by the word progress." 16 That idea was also questioned; Tolstoy observed the reality and saw evil and suffering and came to the conclusion that the phenomenon of progress did not have solely positive content. Between the period of being young, looking for an ethical lodestar and the time after a nervous breakdown, a crisis of outlook, Tolstoy experienced one more "episode" of faith - this time its object was the Russian peasants. The writer believed that these people stored something true and precious, a kind of treasure which was inaccessible for the noble and well-educated strata of the society. He tried to approach that intangible truth, and at the same time, to justify his own life by devoting himself to an educational activity for the good of the peasants. However, aiming at new tasks Tolstoy did not find a refuge from the growing sense of absurdity of life. He describes the beginning of his illness which he called "black abyss,"17 "At first, slight symptoms of ailment occur and an ill person does not pay attention to them; then the symptoms become more and more frequent and they merge into one constant streak of misery. The suffering grows bigger and bigger and, very soon, the ill person realizes that what he regarded as an ailment is in fact the most important thing - it is death." 18

The activities that Tolstoy loved most: taking care of his family and writing, lost their significance. What is more, they became an unbearable burden. In despair the writer asks how he is to bring up his children, when he knows that their lives are pointless, "Why are they to live? Why am I to love, to protect, to bring up and to guard them? For this despair which is inside of me or for that dullness! I love them so I must not hide the truth from them. [...] And death is the truth." 19 Repeating "All is vanity" Tolstoy thinks about committing suicide, "Happy is the one who was not born. Death is better than life. It is necessary to free oneself." ${ }^{20}$ But something prevents the writer from taking the final step. There is a kind of hope which keeps him alive. Tolstoy wants to believe that perhaps he is the one who has lost the right path and wanders about, and that he is the one who looks for meaning of life in the wrong way.

"If I simply accepted that life is pointless, I would be content with the knowledge that it is my lot. But I could not accept it. If I were like a man who lived in a forest and knew that there was no way out, I could carry on; but I was like a man who got lost in that forest and was overwhelmed with terror because of the fact he had lost his way. And he trashes about, he wants desperately to

\footnotetext{
${ }^{16}$ Ibid., p. 102.

${ }^{17}$ Ibid., p. 105.

${ }^{18}$ Ibid., p. 105.

${ }^{19}$ Ibid., p. 109.

${ }^{20}$ Ibid., p. 123.
} 
find a way out; he knows that with each step he is getting lost more and more, and he gets even more horrified by that." 21

In this desperate situation Tolstoy referred to the tool which was tested many times: rational concluding. He was a child of the $19^{\text {th }}$ century; he was brought up in the worship of reason and science, the idea of progress and man reigning over reality. The quest in the domain of knowledge brought Tolstoy back to the initial conclusion: death is the only certain thing.

The conclusion that all kinds of science: empirical, natural and philosophical ones do not solve the fundamental dilemma "why to live" is the next stage in Tolstoy's reasoning. Looping at the detailed a detailed elaboration of Tolstoy's conclusions on each of the above-mentioned fields of knowledge, it is worth reminding that the writer definitely negates reason as a useful tool in his search for answers about the significance of life and death. In Confession, from the perspective of time, Tolstoy interprets these ponderings as an act of inner inertia which was an escape from despair.

"I felt that if I wanted to live and understand the meaning of life, I had to look for it not in those who had lost it and wanted to kill themselves [...]. I looked backwards at huge masses of the ordinary people who have lived, not well-educated, not rich, and I saw something totally different." ${ }^{22}$ Recognizing the invigorating power of faith, he stated that it was faith which linked temporary things to the eternal ones and made human deeds meaningful, "Faith is recognition of the meaning of human life, as a result of which a human being does not destroy himself but is alive. Faith is the power of life." ${ }^{23}$ The last statement constitutes Tolstoy's manifesto. The writer claims that man without religion is a dead creation of the intellect and, sooner or later, will disintegrate. ${ }^{24}$ Tolstoy expresses his thoughts about a struggle between reason and faith, life and death with the following words, "I remember that I lived only then when I believed in God. And here He is. That one without whom life is impossible. To know God and to live is the same. God is life." 25

Thus at the same time the writer's confession brings the conclusion that the noble values are meaningless; its cultural legacy, based on rationalism, does not bring answers to fundamental questions and the intellect, which was to open horizons, leads to nowhere. Paradoxically, to reveal the secret of life, Tolstoy has to introduce the great unknown into his equation: God. By observing peasants'

${ }^{21}$ Ibid., p. 110.

${ }^{22}$ Ibid., p. 129.

${ }^{23}$ Ibid., p. 133.

${ }^{24}$ Fait as invigorating power for man and for culture occurs in many of Tolstoy's writings, among others Чем люди живы, [in:] Полное собрание сочинений, vol. 3; Где вера, там и Бог, [in:] Полное собрание сочинений, vol. 3.

25 Л. Н. Толстой, Исповедь, ор. cit., p. 144. 
life, so different from the existence of his own social class, the writer comes to the conclusion that "he lived a stupid life." "I lost my way not because I thought in a wrong way but because I lived a stupid life. [...] The life of our social class - the rich and well-educated ones - not only repelled me but it also lost all the meaning for me. I regarded all our activities, discussions, science and art as futile entertainment." ${ }^{26}$ The desire to escape from all that was familiar to Tolstoy and that now seems false and idle followed the denial of the whole previous lifestyle. An effort to organize reality, to define some rules to lead a new life was his next steps. Confessing faith, Tolstoy - paradoxically - refers to the intellect in order to prepare texts and to interpret his newly-discovered rules.

\section{Basic elements of Tolstoy's moral-ethical doctrine}

As Andrzej Walicki writes, as early as in 1855 Tolstoy felt a desire to create, "the basis for a new religion: a religion of Christ but purged from faith and mysteriousness; a practical religion which does not promise happiness in heaven but gives fortune to those on earth." ${ }^{27}$ The all-embracing concept of Tolstoy's "religion" was prepared in the 1880s. Tolstoy started it with writing the Gospel anew. He claimed that he wanted to present in a comprehensible way Christ's teachings, which had been falsified by the Orthodox Church. The introduction to the texts shows their fundamental dissimilarity to the Gospel. Tolstoy writes, "The understanding of life lies at the basis of everything. The understanding of life replaced God. It became, according to the words of Jesus, the foundation and the beginning for everything, instead of God. Without it nothing can be alive. ${ }^{28}$ Tolstoy did not only shorten the text of the Gospel but also reformulated some of its fragments and combined them in such a way that they gained a new meaning. The writer's output contains the following profession of faith, "I believe in what follows: I believe in God whom I understand as a Spirit, Love and Source of everything. I believe that he is in me and I am in him. I believe that His will, in the most clear and understandable way, was presented in the teaching of the man Christ, who should not be regarded as God

${ }^{26}$ Ibid., pp. 138-139.

${ }^{27}$ A. Walicki, Zarys myśli rosyjskiej. Od Oświecenia do renesansu religijno-filozoficznego, Kraków 2005, p. 501; However, the texts that contained theses of the "new religion" began to appear after 1879: Krytyka teologii dogmatycznеј (Критика догматического богословия, 1879-1880, 1884), reinterpretation of the four Gospels that Tolstoy called New Gospel (Kраткое изложение Евангелия, 1881), Na сzут polega тоја wiara (В чем моя вера, 1882-1884), Cóż więc powinniśmy robić (Так что же нам делать, 1882-1886), О żусіи (Ожизни, 1887), Królestwo Boże jest w nas (Царство Божие внутри нас, 1893), Nauka chrześcijańska (Христианское учение, 1894-1896), Jеdynе przykazanie (Единая заповедь, 1909) and already mansioned above Droga żyсіа (Путь жизни, 1910).

${ }^{28}$ Qouted after Н. Елеонский, $O$ «Новом Евангелии», op. cit., p. 3. 
and prayed to as it is the biggest superstition." ${ }^{29}$ Gospel's teaching together with its moral obligation to love one's neighbour was incorporated into a complete concept of nature which was understood as a manifestation of the God Spirit and the First Cause. Tolstoy did not recognize the idea of the God-human. He put Christ in the rank of great teachers of mankind, like Solomon and Buddha, consequently rejecting the teaching about the Salvation. Reinterpreting of the canonical text resulted in preparing a moral-ethical system that was to become a practical set of rules how to act in everyday life. Its central part was given to the vague and controversial idea of "not to oppose to evil." 30

It was accompanied by the idea of good. Reading Tolstoy's writings allow us to make the conclusion that the author of Confession equates good with happiness in its subjective dimension. Suffering is juxtaposed with such understanding of good. According to Tolstoy, anguish is a consequence of "stupid life" and lack of understanding of Christ's teachings. Replacing the pair good-evil, the absolute Christian values, with the pair happiness - suffering constitutes for Tolstoy a definite exchange of their meanings by their relativisation. One may have the impression that Tolstoy treats evil with a great dose of leniency, regarding it as something which results from stupidity and incomprehension of other people's orders. As Vasyl Zien'kovski accurately notices, "He [Tolstoy] simply rejects everything that drifted away from good." ${ }^{31}$ Tolstoy omitted some aspects of reality and shaped it in such a way as to adjust it to his doctrine. Its two main elements: the conviction that man is good by his nature and evil is acquired, and the principle of not opposing evil imposed such a vision of reality in which there is no struggle between good and evil because the latter is a strange and weak element.

Tolstoy was sure that following the reinterpreted commandments should enable people to create such reality in which there would be peace and people would change swords for ploughs and enjoy happiness till the end of world existence. ${ }^{32}$ The Christian words "Thy will be done" lose their sense because Tolstoy regards God as immanent in character for man and nature. Man, as an architect of paradise on earth, can rely only on himself, is left alone, he cannot refer to the dogmas of faith, universal values or personal authorities. Tolstoy clearly states that it is possible and recommended to have many teachers and learn from each of them. Kozlov notices that even referring to Jesus as one of the greatest prophets Tolstoy put himself and his own interpretation of the Gospel into the

29 Л. Н. Толстой, Ответ на определение Синода от 20-22 февраля и на полученные мною по этому случаю письма, [in:] Полное собрание сочинений, vol. 16, p. 548.

${ }^{30}$ It triggered a fierce polemic in the Russian newspapers in 1886-1888. See L. Liburska, Późna myśl Totstoja, op. cit., p. 45.

${ }^{31}$ В. В. Зеньковский, op. cit., vol. 1, p. 402.

32 See А. А. Козлов, ор. cit., p. 28. 
centre of his teaching, "It is not the count Tolstoy who follows Christ but Christ is summoned to him. The whole book, and especially its initial parts, is a proof that before looking for true morality in Christ, Tolstoy had already possessed not only the criterion of His teachings but had also known their content." ${ }^{.33}$

Three elements of the doctrine: not opposing evil, not judging others and good life in love clashed with the writer's individualism. Rejecting the personal aspect of God changed an anthropological perspective and led to many contradictions in Tolstoy's outlook; the writer propagated the negation of "oneself" as an inherently false idea, deriving from the fact that everybody has a material body. However, he could not help acting as a strong individualist. ${ }^{34}$ If Tolstoy had wanted to be consequent in shaping his outlook, he should also have rejected "self" in reference to his own life. But he did not do that. On the intellectual level, Tolstoy placed himself above the crowd of ordinary people; in his opinion he was the only one who knew what self-betterment was and what the proper path of life looked like. He preached humility but his everyday conduct was full of arrogance. The same referred to the commandment of love of one's neighbour: it was purely theoretical. Tolstoy did not intercede on behalf of his followers who had been arrested for propagating the ideas of his authorship; he also did not take into account the feelings of his family members. The clash of arrogance and egoism with the imperative of love of one's neighbour and doing good is one of the insolvable contradictions in Tolstoy's moral-ethical doctrine. At the same time it is its great weakness and a proof for its utopia.

\section{Elements of Buddhism}

Tolstoy replaced the idea of God-person with an impersonal element which was everlasting, temporarily incarnated in a human being, thus entangled in matter and, once dead, coming back to the eternal Source. The death of Andrey Bolkonski in War and Peace is a return to the spring, dissolution in light, "Love is good, to die means to pour a spark of immortal love, which is inside of everybody, so it is inside of me, to the common, immortal, eternal source." ${ }^{35}$ The thought about releasing the spark of God's love and returning to the spring was inspired by the Buddhists' philosophy. In the article What is religion Tolstoy stated, "There exists God, the principle (the beginning) of everything; there is a tiny part of that divine principle in a man who can reduce it or spread it with his life." ${ }^{36}$

\footnotetext{
${ }^{33}$ Ibid., p. 34.

${ }^{34}$ See В. В. Зеньковский, op. cit., vol. 1, p. 398.

${ }^{35}$ L. Tołstoj, Wojna i pokój, Kraków 2005, vol. 4, p. 295.

36 Л. Н. Толстой, Что такое религия, [in:] Полное собрание сочинений, vol. 15, p. 317.
} 
The Buddhist inspiration pervades the whole of Tolstoy's moral conception, all his opinions about the essence of man and reality. The writer declared the necessity to be practical and to concentrate oneself on the material reality but at the same time, he promoted the thought that the real man's life was in the world of the spirit where the rules of time and space did not apply, and "The real man's life is beyond time and space." 37 Tolstoy regarded the visible reality as illusory, hiding the truth about the world from man. The statement provokes associations of the Buddhist concept of Maya - the curtain which hides the true nature of things. ${ }^{38}$

Although the writer did not define evil, he repeatedly identified it with fight and violence and he even claimed that engaging in discussion and convincing opponents to change their opinions was evil because it led to the escalation of resistance. The call to avoid any kind of opposition to everything that is brought by reality constitutes another association with Buddhism, in which observation and meditation are the ways for self-betterment. Understanding is a tool to overcome the determinants of the material reality the main feature of which is suffering resulting from ignorance.

Tolstoy's fascination with the religion of the East went far beyond the area of ideas; it also included everyday life: following the ahimsa principle of not harming living creatures, the writer was on a vegetarian diet and, even when he was seriously ill, he refused eating broth.

Despite numerous similarities, one must not associate Buddhism with Tolstoism. Both systems understand differently the final purpose of human life; in Buddhism it is breaking sansara - the cycle of incarnations and attaining nirvana whereas according to Tolstoism it is building paradise on Earth. ${ }^{39}$

\section{Conclusion}

The analysis of Tolstoy's writings during the last thirty years of his life supports the conclusion that the writer presented in a form of a moral-ethical doctrine the features of his worldview that he had worked on between the 1840s and 1870 s. The need to create a "new religion" to a great extent was caused by the crisis which affected the Russian culture. ${ }^{40}$ Many Russian thinkers of that time created apocalyptic visions of the end of our times. Tolstoy was one of them. His doctrine was very attractive because it perfectly matched the nihilistic tendencies which propagated and recommended the destruction of the existing

\footnotetext{
37 Л. Н. Толстой, О жизни, [in:] Полное собрание сочинений, vol. 17, p. 248.

${ }^{38}$ Cf. A. Walicki, op. cit., p. 507.

${ }^{39}$ See A Козлов, оp. cit., p. 70.

${ }^{40}$ See L. Liburska, Późna myśl Totstoja, quasi-uniwersalna synteza, op. cit., p. 47.
} 
state, the Church and social structures, and negated the current anthropological and religious conceptions.

Tolstoy's utopia gained its power from his one-sided look at reality and from his conviction that the elements which are obstacles on the way to moral development and building a community of people, who are unified by the ideas of good and love, can be simply removed. The syncretism of the ideas coming from different sources: the Enlightenment ideology, the Christian Orthodox faith in the version of classic Russian Slavophilism, the philosophy of Rousseau, Buddhism and some revolutionary and anarchistic idea made Tolstoy's doctrine appealing for many social groups.

Regarding the rejection of suffering and the destruction of the idea of God-person, Tolstoy's doctrine resembles the socialist consciousness. It was expressed by one of the heroes in Dostoevsky's novel, Ivan Karamazov, who said, "There is no need to demolish anything. One needs to destroy the idea of God in people. This is where one must start from." 41

\section{Bibliography}

\section{Original sources}

Suchotina-Tołstoj T., Wspomnienia, tr. by M. Okołów-Podhorska, Warszawa 1983.

Толстой Л., Исповедь, [in:] Полное собрание сочинений в двадиати томах, ред. Н. Н. Акопова и др., Москва 1961, vol. 6.

Толстой Л., В чем моя вера, [in:] Полное собрание сочинений в двадияати томах, ред. Н. Н. Акопова и др., Москва 1961, vol. 3.

Толстой Л., Путь жсизи, [in:] Полное собрание сочинений Л. Н. Толстого, Москва 1956, vol. 45.

Tołstoj L., Dziennik (1847-1894), (1895-1910), tr. by M. Leśniewska, Kraków 1973.

Tołstoj L., Myśli o Bogu, tr. by Z. Podgórzec, “Znak” 1974 no. 238.

Tołstojowa Z., Pamiętniki, selected and translated by M. Leśniewska, Kraków 1968.

\section{Secondary sources}

Asmus W. F., Lew Totstoj, Warszawa 1964.

Eichenbaum B., Lew Totstoj, vol. 1-3, Leningrad 1928-1931.

Елеонский Н., О «Новом Евангелии» графа Толстого, Москва 1887.

Gusiew N. N., Letopis'żyzni i tworczestwa L. N. Totstogo, Moscow 1958.

Iskander F., Literatura rosyjska i dwoiste widzenie Totstoja, tr. by W. Tkaczuk, "Znak" 1974 no. 238.

Johnson P., Lew Totstoj: starszy brat Pana Boga, [in:] Johnson, Intelektualiści, tr. by A. Piper, Poznań 1998.

Козлов А. А., Религия графа Л. Н. Толстого, Санкт-Петербург 1888.

\footnotetext{
${ }^{41}$ F. Dostoyevsky, The Brothers Karamazov.
} 
Liburska L., Późna myśl Tołstoja, quasi-uniwersalna synteza, [in:] Wizja świata i człowieka w myśli rosyjskiej, ed. L. Suchanek, Kraków 1998, pp. 45-65.

Romaniuk R., Dramat religijny Totstoja, Warszawa 2008.

Szkłowski W., Lew Tołstoj. Biografia, tr. by R. Granas, Warszawa 2008.

“Уход” и “воскресение” героев Толстого, [in:] В мире Толстого. Сборник статей, Москва 1978, http://metapoetry.narod.ru/liter/lit07.htm. 
